\title{
Wastewater Use in Agriculture: Agronomic Considerations
}

\author{
Manzoor Qadir \\ International Center for Agricultural Research in the Dry Areas (ICARDA), Aleppo, Syria, and \\ International Water Management Institute (IWMI), Colombo, Sri Lanka \\ Liqa Raschid-Sally \\ Pay Drechsel \\ International Water Management Institute (IWMI), Cantonments, Accra, Ghana
}

\section{INTRODUCTION}

The demographic trends and future growth projections suggest that more than $60 \%$ of the global population may suffer water scarcity by the year 2025. ${ }^{[1]}$ Despite improvements in water-use efficiency techniques, water scarce countries will have to increasingly rely on irrigation with marginal-quality water resources. Wastewater generated by domestic, commercial, and industrial uses is an important component of marginal-quality waters. In many developing countries, wastewater is used for crop production in treated, partly treated, diluted, and untreated forms. ${ }^{[2]}$ Estimates suggest that at least 3.5 million ha are irrigated worldwide with different forms of wastewater; ${ }^{[3]}$ the acreage will increase in future as more freshwater will be diverted to household and industrial sectors, which will generate greater volumes of wastewater. $^{[4]}$

Many small-scale farmers in developing countries use wastewater in urban and peri-urban areas to produce vegetables as a market-ready product. In addition, rice, fodder, and industrial crops are produced. In developed countries, treated wastewater is mostly used for landscaping, particularly in cities though extensive use in agriculture occurs as well. ${ }^{[5]}$

The protection of consumer and farmer health and environment are the main concerns associated with uncontrolled wastewater irrigation. ${ }^{[6]}$ Thus, sustainable use of wastewater depends largely on appropriate measures, which address three major aspects: pertinent regulatory policies and institutional arrangements; wastewater treatment per intended reuse option; and agronomic management practices that minimize the health and environmental implications. The focus of this entry is on the agronomic considerations.

\section{AGRONOMIC CONSIDERATIONS FOR WASTEWATER USE}

The implementation of suitable agronomic practices for wastewater irrigation is the key to sustainable

1296 production systems while taking into account the health and environmental implications. Such agronomic considerations can be divided into four major categories: crop selection and diversification in terms of market value, irrigation requirement, and tolerance against ambient stresses; irrigation management based on water quality, and irrigation method, rate, and scheduling; soil-based considerations such as soil characteristics, soil preparation practices, application of fertilizers and amendments if needed, and soil health aspects; and other considerations such as crop harvesting measures, human health protection while working in the field, and awareness of the farmers about the best agronomic practices. The agronomic considerations are interrelated and implicate each other (Fig. 1).

\section{CROP SELECTION AND DIVERSIFICATION}

Crop selection in terms of irrigation requirement is particularly important in water scarce areas where major dependency is based on the nature of the crop, the growth period, and the climatic conditions in the area such as rainfall, and ambient temperature and relative humidity. Since crop evapotranspiration is determined by the climatic factors, it can be estimated by using the meteorological data. Computer models are available that assist in computation of crop water use.

In addition to some metals and metalloids, most treated wastewaters contain appreciable concentrations of salts, which may affect growth and yield. The growth of crops irrigated with saline wastewater is influenced by the osmotic and ion-specific effects, and ionic imbalance leading to deficiency and/or toxicity of some nutrients. In such cases, there would be a need to select crops that can tolerate the salt and ion-specific effects. Guidelines are available that suggest yield potentials of a range of grain, forage, vegetable, and fiber crops as a function of average root zone salinity (see entry Wastewater Use in Agriculture: Saline and Sodic Waters). 


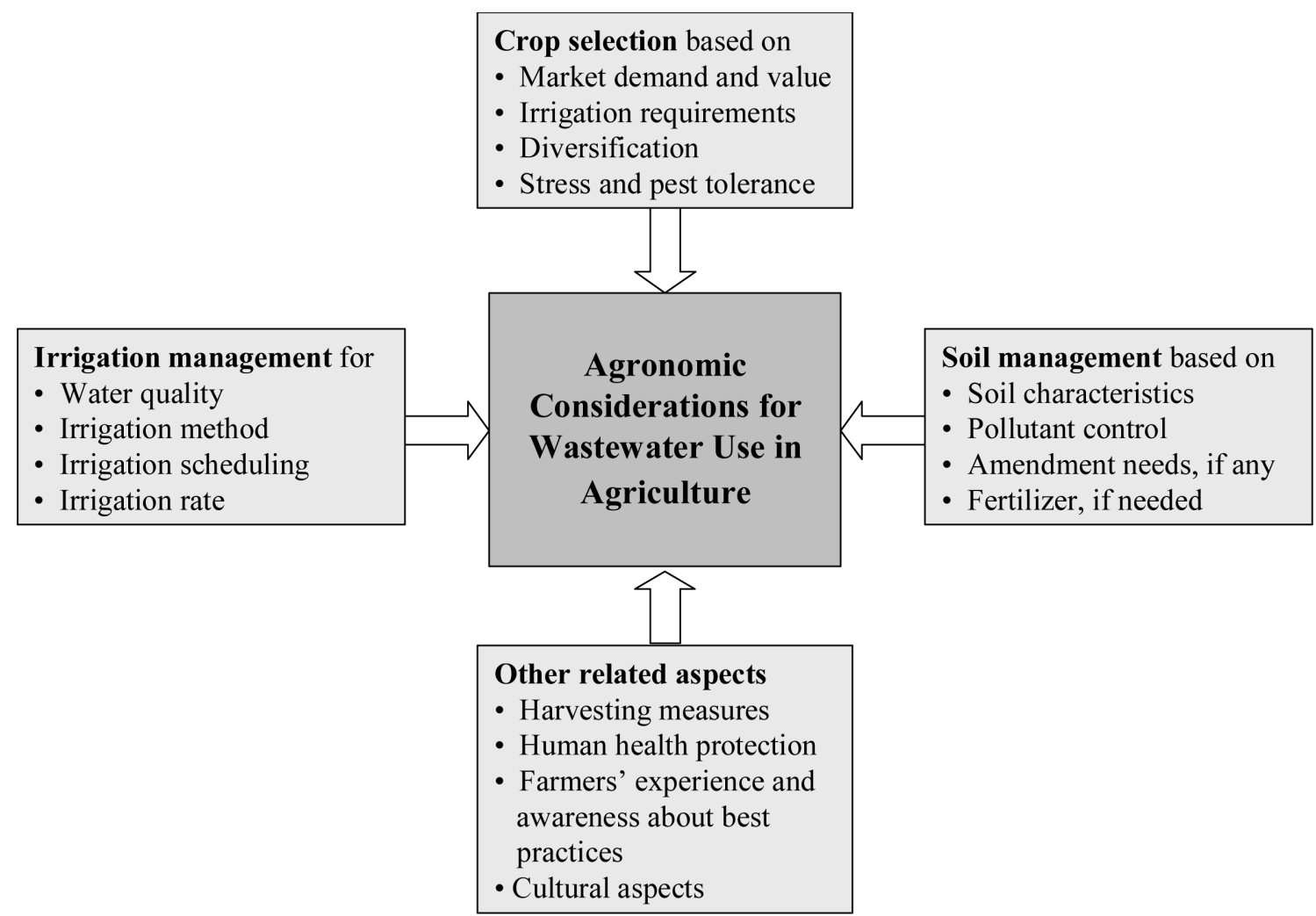

Fig. 1 Schematic illustration of the four main categories of agronomic considerations, which are interrelated and implicate each other.

The selection of crops for irrigation with wastewater also depends on the cost of inputs and the subsequent economic and/or on-farm benefits. However, care should be taken to select the crops that while providing financial benefits to the farmers should not contain excessive levels of metals, metalloids, and biological contaminants, which may have deleterious health effects. The restrictions on crops are feasible and particularly facilitated under the following conditions: strong law enforcement on crop selection; control of public body over water allocation; irrigation project with strong central management; and market demand of the crop(s) promoted for irrigation with wastewater. ${ }^{[7]}$ In general, the highest risk involves consumers and farmers when irrigation with untreated, or inadequately treated, wastewater is practiced for crops that are eaten uncooked such as fresh vegetables. The cultivation of industrial crops such as cotton provides the lowest risks to the consumers, but protection of farmers is still needed ${ }^{[8]}$ The implications relating to irrigation with untreated or partly treated wastewater can be reduced if agroforestry species are grown for non-edible products such as fuel and timber. ${ }^{[9]}$

\section{IRRIGATION MANAGEMENT}

In addition to water supply conditions, climate, soil characteristics, candidate crops, irrigation cost, and farmer's skill, the choice of irrigation method with wastewater depends on water quality, possible contamination of the harvest material, and health and environmental implications. Based on possible risks of contamination by different metals and metalloids, water quality guidelines for wastewater irrigation are available (Table 1).

Wastewater irrigation can be accomplished by the following approaches: surface or flood irrigation where water is applied directly on the soil surface by gravity; furrow irrigation; high pressure sprinkler irrigation; and micro-irrigation such as drip and trickle irrigation. Flood irrigation is the lowest cost method with low water use efficiency and low level of health protection for the farmers and consumers. With medium level of health protection, furrow irrigation needs land leveling. It is suitable when there is a greater leaching need to remove high levels of salts. Without the need of land leveling, irrigation with sprinklers involves medium to high cost and medium water use efficiency. It has low levels of health protection because of aerosols. Irrigation scheduling aspects such as irrigation during night and no irrigation under windy conditions are important considerations while using sprinklers. Drip irrigation systems are costly, but highly efficient in water use along with the highest levels of health protection. However, filtration is needed to prevent clogging of emitters. ${ }^{[9]}$ 
Table 1 Recommended maximum concentrations (RMC) of selected metals and metalloids in irrigation water

\begin{tabular}{|c|c|c|}
\hline Element & $\operatorname{RMC}\left(\mathrm{mg} \mathrm{L}^{-1}\right)$ & Remarks \\
\hline Aluminum & 5.00 & $\begin{array}{l}\text { Can cause non-productivity in acid soils }(\mathrm{pH}<5.5) \text {, but more alkaline soils at } \mathrm{pH}>7.0 \\
\text { will precipitate the ion and eliminate any toxicity }\end{array}$ \\
\hline Arsenic & 0.10 & $\begin{array}{l}\text { Toxicity to plants varies widely, ranging from } 12 \mathrm{mg} \mathrm{L}^{-1} \text { for Sudan grass to less than } \\
0.05 \mathrm{~m} \mathrm{~L}^{-1} \text { for rice }\end{array}$ \\
\hline Beryllium & 0.10 & $\begin{array}{l}\text { Toxicity to plants varies widely, ranging from } 5 \mathrm{mg} \mathrm{L}^{-1} \text { for kale to } 0.5 \mathrm{mg} \mathrm{L}^{-1} \text { for bush } \\
\text { beans }\end{array}$ \\
\hline Cadmium & 0.01 & $\begin{array}{l}\text { Toxic at concentrations as low as } 0.1 \mathrm{mg} \mathrm{L}^{-1} \text { in nutrient solution for beans, beets } \\
\text { and turnips. Conservative limits recommended }\end{array}$ \\
\hline Chromium & 0.10 & $\begin{array}{l}\text { Not generally recognized as an essential plant growth element. Conservative limits } \\
\text { recommended }\end{array}$ \\
\hline Cobalt & 0.05 & $\begin{array}{l}\text { Toxic to tomato plants at } 0.1 \mathrm{mg} \mathrm{L}^{-1} \text { in nutrient solution. It tends to be inactivated by } \\
\text { neutral and alkaline soils }\end{array}$ \\
\hline Copper & 0.20 & Toxic to a number of plants at 0.1 to $1.0 \mathrm{mg} \mathrm{L}^{-1}$ in nutrient solution \\
\hline Iron & 5.00 & $\begin{array}{l}\text { Non-toxic to plants in aerated soils, but can contribute to soil acidification and loss of } \\
\text { availability of phosphorus and molybdenum }\end{array}$ \\
\hline Lithium & 2.50 & $\begin{array}{l}\text { Tolerated by most crops up to } 5 \mathrm{mg} \mathrm{L}^{-1} \text {. Mobile in soil. Toxic to citrus at low } \\
\text { concentrations with recommended limit of }<0.075 \mathrm{mg} \mathrm{L}^{-1}\end{array}$ \\
\hline Manganese & 0.20 & Toxic to a number of crops at a few-tenths to a few $\mathrm{mg} \mathrm{L}^{-1}$ in acidic soils \\
\hline Molybdenum & 0.01 & $\begin{array}{l}\text { Non-toxic to plants at normal concentrations in soil and water. Can be toxic to livestock } \\
\text { if forage is grown in soils with high concentrations of available molybdenum }\end{array}$ \\
\hline Nickel & 0.20 & Toxic to a number of plants at 0.5 to $1.0 \mathrm{mg} \mathrm{L}^{-1}$; reduced toxicity at neutral or alkaline $\mathrm{pH}$ \\
\hline Lead & 5.00 & Can inhibit plant cell growth at very high concentrations \\
\hline Selenium & 0.02 & $\begin{array}{l}\text { Toxic to plants at low concentrations and toxic to livestock if forage is grown in soils } \\
\text { with relatively high levels of selenium }\end{array}$ \\
\hline Zinc & 2.00 & $\begin{array}{l}\text { Toxic to many plants at widely varying concentrations; reduced toxicity } \\
\text { at } \mathrm{pH} \geq 6.0 \text { and in fine textured or organic soils }\end{array}$ \\
\hline
\end{tabular}

The maximum concentration is based on a water application rate, which is consistent with good irrigation practices $\left(10000 \mathrm{~m}^{3} \mathrm{ha}^{-1} \mathrm{yr}^{-1}\right)$. If the water application rate greatly exceeds this, the maximum concentrations should be adjusted downward accordingly. No adjustment should be made for application rates less than $10000 \mathrm{~m}^{3} \mathrm{ha}^{-1} \mathrm{yr}^{-1}$. The values given are for water used on a long-term basis at one site. Source: Adapted from Ref. ${ }^{[10]}$.

Financial consideration is an important factor that drives the choice of irrigation method. Nevertheless, the health risks associated with different methods as well as water savings should also be considered. ${ }^{[8]}$ Recently revised guidelines by the World Health Organization provide complementary options for wastewater treatment and control of human exposures (see entry on Wastewater Use in Agriculture: Empirical Evidence).

\section{SOIL-BASED INTERVENTIONS}

Good management practices play a crucial role in the preservation of the soil properties while irrigating with wastewater. Soil-based interventions are important, particularly in case of inorganic contaminants, which usually accumulate in the upper part of the soil because of strong adsorption and precipitation phenomena. For moderate levels of metals and metalloids in wastewater, there is no particular management needed if the soils are calcareous, i.e., contain appreciable levels of calcite. However, metal ions may be a problem in acid soils, which need specific management measures such as liming, avoiding use of fertilizers with acidic reactions, and selection of crops that do not accumulate the metals of concern. ${ }^{[10]}$ In case of irrigation with wastewater containing elevated levels of sodium, care should be taken to avoid soil structure deterioration. Application of a source of calcium such as gypsum is desirable. Procedures are available to determine the rate of gypsum application to mitigate the effects of sodium resulting from sodic wastewater irrigation.

The quality and depth of groundwater prior to wastewater irrigation determine the detrimental effects of salts, nitrates, and metals reaching groundwater. The deeper the groundwater, the longer it will take to have such effects. In case of shallow groundwater or coarsetextured soils - sandy soils that are highly permeablecare must be taken to prevent groundwater pollution. 
Table 2 Contribution of irrigation with recycled wastewater (treated urban wastewater) in terms of nutrient addition to the soil

\begin{tabular}{|c|c|c|c|}
\hline \multirow[b]{2}{*}{ Nutrient } & \multirow[b]{2}{*}{$\begin{array}{l}\text { Concentration } \\
\left(\mathrm{mg} \mathrm{L}^{-1}\right)\end{array}$} & \multicolumn{2}{|c|}{$\begin{array}{c}\text { Fertilizer contribution } \\
\left(\mathrm{kg} \mathrm{ha}^{-1}\right)\end{array}$} \\
\hline & & $\begin{array}{l}\text { Irrigation at } \\
3000 \mathrm{~m}^{3} \mathrm{ha}^{-1}\end{array}$ & $\begin{array}{l}\text { Irrigation at } \\
5000 \mathrm{~m}^{3} \mathrm{ha}^{-1}\end{array}$ \\
\hline Nitrogen & $16-62$ & $48-186$ & $80-310$ \\
\hline Phosphorus & $4-24$ & $12-72$ & $20-120$ \\
\hline Potassium & $2-69$ & $6-207$ & $10-345$ \\
\hline Calcium & 18-208 & $54-624$ & $90-1040$ \\
\hline Magnesium & $9-110$ & $27-330$ & $45-550$ \\
\hline Sodium & $27-182$ & $81-546$ & $135-910$ \\
\hline
\end{tabular}

Derived from the data on nutrient concentrations in recycled wastewater and volume of applied irrigation. Source: From Ref. ${ }^{[7]}$.

Although the fertilizer value of wastewater is of great importance, as nutrients in wastewater contribute to crop requirements, periodic monitoring is required to estimate the nutrient loads in wastewater and adjust fertilizer applications. ${ }^{[7]}$ Excessive nutrients can cause nutrient imbalances, undesirable vegetative growth, delayed or uneven maturity, and can also reduce crop quality and pollute groundwater and surface water. The amount of nutrients applied via wastewater irrigation can vary considerably if it is raw, treated, or diluted with stream water. The contribution of irrigation with recycled wastewater in terms of nutrient $\mathrm{T} 2$ addition to the soil is given in Table 2.

\section{OTHER CONSIDERATIONS}

Farmers who use untreated, or inadequately treated, wastewater are exposed to health risks, which can be reduced by implementing protective measures such as wearing boots and gloves, and washing their arms and legs after immersion in wastewater to prevent the spread of infections (see entry on Wastewater Use in Agriculture: Public Health). For certain crops, farmers also can suspend application sometime prior to harvest, to reduce potential harm to consumers. Vegetables can be washed (with good-quality water free of pathogens, viruses, and contaminants) before sale or consumed along with improvement in the storage methods. The awareness and education of the farmers about the best agronomic interventions is an essential step in sustainable wastewater irrigation.

\section{ACKNOWLEDGMENTS}

This publication is a part of the joint initiative of the International Center for Agricultural Research in the Dry Areas (ICARDA) and International Water Management Institute (IWMI) addressing the assessment and management of marginal-quality water resources and salt-prone soils.

\section{REFERENCES}

1. Seckler, D.; Amerasinghe, U.; Molden, D.; de Silva, R.; Barker, R. World Water Demand and Supply 1990 to 2025: Scenarios and Issues; IWMI: Colombo, Sri Lanka, 1998.

2. Hussain, I.; Raschid, L.; Hanjra, M.A.; Marikar, F.; Van der Hoek, W. Wastewater Use in Agriculture: Review of Impacts and Methodological Issues in Valuing Impacts, Working Paper 37; IWMI: Colombo, Sri Lanka, 2002.

3. Jimenez, B.; Asano, T. Acknowledge all approaches: The global outlook on reuse. Water21 December 2004, $32-37$.

4. Scott, C.; Faruqui, N.I.; Raschid-Sally, L. Wastewater Use in Irrigated Agriculture: Confronting the Livelihood and Environmental Realities; CABI Publishing: Wallingford, UK; Colombo, Sri Lanka; Ottawa, Canada, 2004; 1-10.

5. Asano, T.; Ed. Wastewater Reclamation and Reuse, Water Quality Management Library Series (Volume 10). CRC Press, Boca Raton, Florida, 1998 (ISBN10.1566766206) $1528 \mathrm{pp}$.

6. Drechsel, P.; Blumenthal, U.J.; Keraita, B. Balancing health and livelihoods: adjusting wastewater irrigation guidelines for resource-poor countries. Urban Agric. Magazine 2002, 8, 7-9.

7. Lazarova, V.; Bahri, A. Water Reuse for Irrigation: Agriculture, Landscapes, and Turf Grass; CRC Press: Boca Raton, 2005.

8. WHO. Guidelines for the Safe Use of Wastewater, Excreta and Grey Water: Wastewater Use in Agriculture (Volume 2); WHO, FAO, UNEP: Geneva, 2006.

9. Minhas, P.S.; Samra, J.S. Wastewater Use in Peri-urban Agriculture: Impacts and Opportunities; Central Soil Salinity Research Institute: Karnal, India, 2004.

10. Ayers, R.S.; Westcot, D.W. Water Quality for Agriculture, Irrigation and Drainage Paper 29 (Rev. 1); FAO: Rome, 1985. 